\title{
Robotic Ventral Mesh Rectopexy: Where do we Stand?
}

\section{Robotik Ventral Meş Rektopeksi: Güncel Olarak Neredeyiz?}

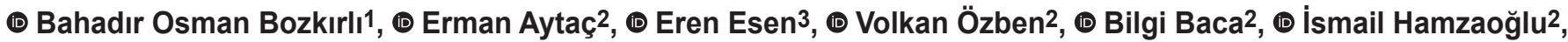 \\ (D) Tayfun Karahasanoğlu2 \\ ${ }^{1}$ Ankara Research and Training Hospital, Department of General Surgery, Ankara, Turkey \\ ${ }^{2}$ Acıbadem Mehmet Ali Aydınlar University Faculty of Medicine, Department of General Surgery, İstanbul, Turkey \\ ${ }^{3}$ New York University Langone Medical Center, Department of Surgery, Inflammatory Bowel Disease Center, New York, United States of America
}

\section{HIIIIII| ABSTRACT}

This paper aims to review the current status of robotic ventral mesh rectopexy (VMR). The articles reporting the outcomes of patients who underwent robotic VMR were reviewed and evaluated. Complications of robotic VMR ranged between $0 \%$ to 25\%, the majority of them were minor complications. Longer operating time and higher hospital expenses are the major limitations of robotic surgery compared to laparoscopy. As an emerging technique, robotic VMR promises good outcomes. Robotic VMR seems to be a safe and effective surgical technique in the treatment of rectal prolapse.

Keywords: Robotic, rectopexy, ventral mesh repair

\section{|IIIIIII| ÖZ}

$\mathrm{Bu}$ makalede robotik ventral meş rektopeksi (VMR) operasyonunun güncel tekniği ve sonuçları gözden geçirilmiştir. Robotik VMR ile ilişkili komplikasyonlar \%0 ile \%25 arasında değişen ve çoğunluğu minimal komplikasyonlardır. Daha uzun ameliyat süresi ve daha yüksek hastane maliyeti, laparoskopiye kıyasla robotik cerrahinin en önemli kısıtlamalarıdır. Gelişen bir teknik olarak, robotik VMR iyi sonuçlar vaat etmekte ve rektal prolapsus tedavisinde etkili bir cerrahi teknik olarak görünmektedir.

Anahtar Kelimeler: Robotik, rektopeksi, ventral meş onarım

\section{Introduction}

Rectal prolapse and related conditions such as rectocele and enterocele are socially debilitating conditions. ${ }^{1,2}$ Among many effective surgical and medical treatment options defined, there is no standard treatment for rectal prolapse. Proper management of rectal prolapse should be tailored individually based on presence of pelvic floor defects, vaginal prolapse, severe constipation, prior perineal trauma and surgical history. ${ }^{3,4}$ Similar to many other disorders of the pelvic floor, multidisciplinary approach is required for treatment of rectal prolapse. ${ }^{4}$ Surgical treatment of rectal prolapse has evolved substantially after the introduction of laparoscopy. ${ }^{5}$ Currently, laparoscopic ventral mesh rectopexy (VMR) is the main surgical treatment of choice for rectal prolapse. The original procedure, described by D'Hoore et al. ${ }^{6}$, involves re-placing of the prolapsed rectum by suspending it to the anterior longitudinal ligament of the sacrum using a mesh anteriorly. Laparoscopic VMR improves the symptoms of obstructed defecation by fixing the rectal prolapse without creation of an anastomosis. ${ }^{7,8}$ However, laparoscopic technique has some limitations while working in confined spaces such as deep pelvis, intracorporeal suturing and positioning the mesh. ${ }^{9}$ Robotics, which has been developed to overcome limitations of laparoscopy, provides better visualization and increased maneuverability in confined spaces and complicated conditions. ${ }^{10}$ This paper aims to review the current status of the robots in VMR for the treatment of rectal prolapse. 


\section{Review Content}

Articles reporting the outcomes of patients who underwent robotic VMR were extracted. The extracted articles were reviewed in terms of operation times, presence of conversion to conventional laparoscopy or open surgery, postoperative complications, length of hospital stay, long-term functional results, recurrences, and costs.

\section{Perioperative Course}

Mechanical bowel preparation is used preoperatively in all patients. For deep vein thrombosis prophylaxis, compression stockings and low molecular weight heparin (before and after 12 hours of surgery) are used. After induction of anesthesia, an orogastric tube is inserted and it is removed before extubation, following completion of the surgical operation. Patient is positioned in a modified lithotomy position. The arms are tucked and the body is stabilized with the pads around the shoulders. The da-Vinci Xi ${ }^{\circledast}$ platform is used in our operations, exclusively. After routine cleaning with povidone-iodine, the ports are placed in a straight-line $8 \mathrm{~cm}$ apart horizontally. An $8 \mathrm{~mm}$ accessory port with air seal may be placed in the right lower quadrant in complicated cases. The robot is docked at a 30-degree angle along the left side. The key steps of the procedure were identification of the promontorium, creation of the peritoneal flaps, dissection of the recto-vaginal/vesical septum down to the pelvic floor, mesh placement and closure of the peritoneal flaps. We previously published our operative technique in details. ${ }^{11}$ Patient-controlled analgesia is used for all patients. Patients are asked to walk and to perform breathing exercises within the first postoperative day. Oral feeding is also started in postoperative day 1 . The urinary catheter is removed one day after surgery. Discharge criteria include tolerance of meals without nausea or vomiting, established bowel function, adequate pain management with oral analgesia and independent walk.

\section{Discussion}

Laparoscopic VMR has gained popularity for the surgical treatment of rectal prolapse since it was first described. ${ }^{9,12}$ Many studies have reported the safety of this procedure and good functional results with acceptable complication rates post-operatively. ${ }^{7}$ However, two-dimensional imaging, limited mobility of laparoscopic instruments and working in a confined space such as pelvis are the factors that increase the complexity of VMR when performed laparoscopically. ${ }^{9}$ Due to those factors, the learning curve of laparoscopic VMR is remarkably long and lack of experience has been shown to be associated with worse outcomes. ${ }^{9,13}$ It has been reported that the number of cases needed to be performed to gain dexterity for providing clinically good quality of life was in between 82 and 105 cases and for standardizing the operating time was around 54 cases. ${ }^{13}$ Considering all the advantages of the robotic platform including better visualization and increased maneuverability in confined spaces and complicated conditions, VMR seems as an ideal procedure for robotic technique. ${ }^{9}$ Taking into account its technical advantages, the learning curve of robotic VMR also may be shorter (18 cases) compared to laparoscopy. ${ }^{9,14}$ Thus, VMR is being increasingly performed with robotic technique. . $^{27,15,16}$

\section{Complications}

After the adoption of laparoscopic surgery, the complication rates of rectopexy significantly reduced. ${ }^{17}$ Overall complication rates were between 0 and $23.5 \%$ after laparoscopic VMR, major complication rates ranged from 0 to $7.7 \%$, and perioperative mortality was reported to occur between 0 and $1.1 \%{ }^{7}$ Similarly, complications of robotic VMR ranged from $0 \%$ to $25 \%$, and the majority of them were minor complications. ${ }^{14,16,18,19,20,21,22,23,24}$ The largest series of robotic VMR reported a 1.9\% intraoperative complication rate, and $1.9 \%$ and $7.0 \%$ major and minor early postoperative complication rates, respectively. The mortality rate was found to be $0.4 \%$. In this study, late major and minor complications were seen in $3.5 \%$ and $7.1 \%$ of the patients, respectively. ${ }^{2}$

Intraoperative complications of minimally invasive VMR were vaginal perforation, rectum perforation and hemorrhage. $2,18,25$ Postoperative complications were wound hematoma, surgical site infection, subcutaneous emphysema, urinary retention, urinary tract infections, ileus, mesh erosion, fistula formation, sacral discitis and incisional hernia. . $^{94,25,26,27,28}$ The studies reporting the outcomes of robotic VMR were summarized in Table 1.

In a meta-analysis comparing robotic and laparoscopic VMR, reviewing 242 patients, robotic surgery was shown to have less operative morbidity. ${ }^{29}$ Another metaanalysis that reviewed 3 studies for early complications of robotic and laparoscopic VMR reported fewer wound complications, urinary tract infection, postoperative ileus and abdominal pain in the robotic group, but those trends were not statistically significant. ${ }^{26}$ Male sex and history of having previous abdominal surgeries were the risk factors associated with operative morbidity in patients undergoing VMR. ${ }^{9}$ Dyspareunia and recto-vaginal fistula are common mesh related complications related to VMR. ${ }^{7,30}$ A study conducted by Evans et al. ${ }^{31}$ including 2203 patients reported 2\% general mesh erosion in a median time of 23 months after laparoscopic VMR. In other studies, mesh related complications were reported between 0 and $6.7 \%{ }^{7}$ 
Table 1. Main outcomes of robotic ventral mesh rectopexy

\begin{tabular}{|c|c|c|c|c|c|c|}
\hline Study & Operation & No of operations & $\begin{array}{l}\text { Follow-up time } \\
\text { (median) }\end{array}$ & Complications & Recurrence & Efficiency \\
\hline de Hoog et al. ${ }^{32}$ & $\begin{array}{l}\text { RR vs LR vs OR. } \\
\text { Wells or VMR }\end{array}$ & $\begin{array}{l}14 \text { robot-19 } \\
\text { lapaproscopy (1 } \\
\text { conversion) }\end{array}$ & Short term & $\begin{array}{l}\text { Robot } 2 \text { postop } \\
\text { constipation- } \\
\text { laparoscopy } 3 \text { postop } \\
\text { constipation }\end{array}$ & N/A & N/A \\
\hline Wong et al. ${ }^{38}$ & RVMR or LVMR & $\begin{array}{l}15 \text { robot-23 } \\
\text { laparoscopy-3 } \\
\text { laparotomy }\end{array}$ & 12 months & 2 recurrence & $\begin{array}{l}2 \text { patients ( } 7-3 \\
\text { months) }\end{array}$ & $\begin{array}{l}\text { ODS score }>6 \\
\text { achieved a } \\
\text { significant } \\
\text { improvement in } \\
\text { postoperative } \\
\text { scores }\end{array}$ \\
\hline Wong et al. ${ }^{16}$ & RVMR or LVMR & $\begin{array}{l}19 \text { robot-41 } \\
\text { laparoscopy-3 } \\
\text { laparotomy }\end{array}$ & 6 months & $\begin{array}{l}2 \text { ileus } \\
\text { (laparotomy)-3 UTI }\end{array}$ & None & N/A \\
\hline $\begin{array}{l}\text { Perrenot et al. }{ }^{14} \\
\text { (2002-2006 } 17 \\
\text { patients delorme.) }\end{array}$ & $\begin{array}{l}\text { Robotic assisted } \\
\text { laparoscopy }\end{array}$ & $\begin{array}{l}72 \text { robot-5 } \\
\text { laparotomy ( } 16 \\
\text { ventral-52 alateral-9 } \\
\text { sigmoid res) }\end{array}$ & 52.5 months & $\begin{array}{l}3 \text { rectal wound-2 } \\
\text { urinary infection-2 } \\
\text { presacral collection-1 } \\
\text { hemorrhage }\end{array}$ & $\begin{array}{l}9 \text { patients-> } 5 \\
\text { resurgery->3 } \\
\text { second } \\
\text { recurrence ( } 1 \\
\text { ventral rectopexy } \\
\text { recurrence) }\end{array}$ & Statistics N/A \\
\hline $\begin{array}{l}\text { Mäkelä-kaikkonen } \\
\text { et al. }{ }^{18}\end{array}$ & RVMR-LVMR & $\begin{array}{l}20 \text { robot-20 } \\
\text { laparoscopy }\end{array}$ & 3 months & $\begin{array}{l}1 \text { vaginal perforation } \\
\text { (robot complications) } \\
\text {-1 UTI }\end{array}$ & None & $\begin{array}{l}\text { Subjective benefit } \\
(\% 80)\end{array}$ \\
\hline Mantoo et al. ${ }^{34}$ & RVMR & $\begin{array}{l}50 \text { robot-1 } \\
\text { laparotomy }\end{array}$ & 14 months & 3 UTI-3 recurrence & 3 patients & N/A \\
\hline $\begin{array}{l}\text { Mäkelä-Kaikkonen } \\
\text { et al. }{ }^{33}\end{array}$ & RVMR-LVMR & $\begin{array}{l}16 \text { robot-14 } \\
\text { laparoscopy }\end{array}$ & 3 months & $\begin{array}{l}\text { Robot-fever, } \\
\text { hematoma of rectus } \\
\text { Laparoscopy-perineal } \\
\text { pain }\end{array}$ & None & $\begin{array}{l}\text { Reduction of } \\
\text { prolapses in MR } \\
\text { defecography }\end{array}$ \\
\hline Faucheron et al. ${ }^{21}$ & RVMR-LVMR & $\begin{array}{l}10 \text { robot-10 } \\
\text { laparoscopy }\end{array}$ & 1 month & None & None & N/A \\
\hline van Iersel et al. ${ }^{7}$ & RVMR & $\begin{array}{l}51 \text { robot (1 } \\
\text { conversion) }\end{array}$ & 12.5 months & $\begin{array}{l}\text { Constipation 3- UTI- } \\
\text { hematoma-abscess } \\
\text { of proximal bladder- } \\
\text { Hypokalemia (early) } \\
\text { ACNES 2- Perforating } \\
\text { vaginal suture- } 2 \text { UTI } \\
\text { (late). Erosion of } \\
\text { mesh (1) }\end{array}$ & $\begin{array}{l}1 \text { distal } \\
\text { rectocele-1 } \\
\text { asymptomatic } \\
\text { cystocele }\end{array}$ & $\begin{array}{l}\text { Anatomical, } \\
\text { functional increase } \\
\text { Pescatori, Wexner, } \\
\text { Vaizey, QOL } \\
\text { better scores, } \\
\text { better sexual } \\
\text { health }\end{array}$ \\
\hline
\end{tabular}

RR: Robotic rectopexy, LR: Laparoscopic rectopexy, OR: Open rectopexy, VMR: Ventral mesh rectopexy, LVMR: Laparoscopic ventral mesh rectopexy, RVMR: Robotic ventral mesh rectopexy, N/A: Not applicable, ODS: Obstructed defecation score, UTI: Urinary tract infection, ACNES: Anterior Cutaneous Nerve Entrapment syndrome, QOL: Quality of life, MR: Magnetic resonance 
After robotic VMR, to our knowledge, only one case of mesh erosion was stated in a study of 258 patients after a mean time of 23.5 months. ${ }^{2}$ However, larger studies with longer followup are needed to evaluate postoperative complications after robotic VMR.

\section{Operation Time}

The operation times were significantly longer in robotic VMR compared to laparoscopy in all clinical studies and two meta-analyses, except 2 of them showing no differences. ${ }^{15,16,18,19,20,21,26,29,32,33}$ While robotic VMR seems disadvantageous when compared to laparoscopic VMR due to prolonged operation time, operative experience and standardization of the surgical technique may reduce duration of surgery. ${ }^{34}$ Long operation time in the robotic VMR was not associated with increased risk of postoperative morbidity in any of the prior studies.

\section{Conversion to Open Surgery}

Conversion to open surgery from laparoscopic VMR was reported between $0-10 \%{ }^{7,16}$ Majority of conversions were due to extensive intra-abdominal adhesions. ${ }^{7}$ Up until now, no differences were reported so far in any of the clinical trials or in either of the two meta-analyses comparing laparoscopic and robotic VMR in terms of conversion to open surgery. $15,16,18,19,26,29,33$

\section{Length of Hospital Stay}

The length of hospital stay was generally reported as similar after laparoscopic and robotic VMR..$^{15,16,18,19,20}$ Only in the study by de Hoog et al., ${ }^{32}$ the length of hospital stay after robotic VMR was significantly shorter than the laparoscopy and the open surgery group. While a meta-analysis conducted by Ramage et al. ${ }^{26}$ showed no differences in terms of length of stay (LOS) between laparoscopic and robotic VMRs, other meta-analysis conducted by Rondelli et al. ${ }^{29}$ showed shorter LOS after robotic VMR.

\section{Cost}

There are only two studies comparing the costs of laparoscopic and robotic VMR. ${ }^{15,21}$ In both of these studies, the robotic procedures were associated with higher costs. Heemserk et al. reported that costs were 557.29 Euros (or: 745.09 dollars) higher in robotic surgery when compared to laparoscopy. ${ }^{15}$ Faucheron et al ${ }^{21}$ reported that robotic rectopexy was associated with 5359 Euros additional cost per procedure (9088 vs 3729 euros per procedure, $\mathrm{p}<0.001)$ compared to laparoscopic VMR. ${ }^{21}$ As seen from these trials and considering the expense of the dock console and devices, and also the longer occupation time of the operating room, robotic technique is apparently more expensive in the short term. However, a long-term analysis for cost-effectiveness of robotic and laparoscopic VMR is still lacking.

\section{Long Term Outcomes: Functional Results and Recurrence}

The purpose of rectal prolapse surgery is to correct the prolapse together with its consecutive functional impairments and to protect or restore fecal continence, without causing a new onset or worsened constipation. ${ }^{6}$ VMR, which avoids full rectal mobilization and transection of the lateral stalks, and thus limits the autonomic nerve damage, was developed in the search to reduce postoperative constipation. ${ }^{6}$ As compared with other techniques, metaanalyses confirmed that VMR was associated with less constipation postoperatively. ${ }^{7,35,36}$ Also, the laparoscopic VMR procedure was demonstrated to decrease obstructed defecation (52-84.2\%) and incontinence (50-93\%). ${ }^{7}$

After the introduction of robotic surgery, a number of studies reported their functional results of robotic VMR,

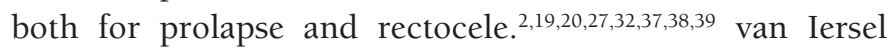
et al. $^{2}$ reported a significant overall improvement in obstructive defecation (78.6\%) and fecal incontinence $(63.7 \%)$ in 258 consecutive patients with rectal prolapse. Other studies also showed an improvement in obstructive defecation symptoms $s^{19,38,39}$, fecal incontinence ${ }^{19,20,37}$, and sexual function ${ }^{27,28,39}$ following robotic VMR.

While two clinical studies comparing the outcomes of robotic and laparoscopic VMR found no difference regarding anorectal functions ${ }^{32,39}$, two other papers reported advantages of robotic VMR over laparoscopic VMR such as significant improvement in obstructed defecation ${ }^{19}$, fecal incontinence and emotional status ${ }^{20}$.

As an important indicator of long-term success, recurrence of rectal prolapse following minimally invasive repair stays similar to open surgery. ${ }^{7}$ The largest observational study of laparoscopic VMR described a 10 year recurrence rate of $8.2 \%$ for patients undergoing external rectal prolapse repair. ${ }^{40}$ The implementation of advanced technology to prolapse surgery does not seem to have changed the recurrence rates. In the studies comparing the two techniques of VMR, recurrences are reported to be from 0 to $7 \%$ for the robotic and 0 to $8 \%$ for the laparoscopic procedures, and were comparable to observational laparoscopic VMR studies. ${ }^{7}$ A meta-analysis reviewing 5 studies and 307 patients, and another reviewing 4 studies and 244 patients for recurrence found no significant differences in the recurrence of rectal prolapse between robotic and laparoscopic VMR. ${ }^{26,29}$ However, the follow-up periods of these clinical studies comparing the two procedures are relatively short. The only study that observed the long-term results (52.5 months of mean follow-up time) of robotic VMR reported a recurrence rate of $12.8 \% .^{14}$ 


\section{Conclusions}

While robotic VMR seems as a safe and effective surgical technique for treatment of rectal prolapse, data about long term outcomes are needed to reveal its role for treatment of rectal prolapse.

\section{Ethics}

Peer-review: Internally peer-reviewed.

\section{Authorship Contributions}

Concept: B.O.B., E.A., E.E., V.Ö., B.B., I.H., T.K., Design: B.O.B., E.A., E.E., V.Ö., B.B., I.H., T.K., Data Collection or Processing: B.O.B., E.A., E.E., V.Ö., B.B., I.H., T.K., Analysis or Interpretation: B.O.B., E.A., E.E., V.Ö., B.B., I.H., T.K., Literature Search: B.O.B., E.A., E.E., V.Ö., B.B., İ.H., T.K., Writing: B.O.B., E.A., E.E., V.Ö., B.B., İ.H., T.K.

\section{References}

1. Melton GB, Kwaan MR. Rectal Prolapse. Surg Clin North Am 2013;93:187198.

2. van Iersel JJ, Formijne Jonkers HA, Paulides TJC, Verheijen PM, Draaisma WA, Consten ECJ, Broeders IAMJ. Robot-Assisted Ventral Mesh Rectopexy for Rectal Prolapse: A 5-Year Experience at a Tertiary Referral Center. Dis Colon Rectum 2017;60:1215-1223.

3. Bordeianou L, Hicks CW, Kaiser AM, Alavi K, Sudan R, Wise P E. Rectal Prolapse: An Overview of Clinical Features, Diagnosis, and Patient-Specific Management Strategies. J Gastrointes Surg 2013;18:1059-1069.

4. Jallad K, Gurland B. Multidisciplinary Approach to the Treatment of Concomitant Rectal and Vaginal Prolapse. Clin Colon Rectal Surg 2016;29:101-105.

5. Van Geluwe B, Wolthuis A, D'Hoore A. Laparoscopy for pelvic floor disorders. Best Pract Res Clin Gastroenterol 2014;28:69-80.

6. D'Hoore A, Cadoni R, Penninckx F. Long-term outcome of laparoscopic ventral rectopexy for total rectal prolapse. Br J Surg 2004;91:1500-1505.

7. van Iersel JJ, Paulides TJ, Verheijen PM, Lumley JW, Broeders IA, Consten EC.Current status of laparoscopic and robotic ventral mesh rectopexy for external and internal rectal prolapse. World J Gastroenterol 2016;22:49774987.

8. Fu CW, Stevenson AR. Risk Factors for Recurrence After Laparoscopic Ventral Rectopexy. Dis Colon Rectum 2017;60:178-186.

9. Gurland B. Ventral mesh rectopexy: is this the new standard for surgical treatment of pelvic organ prolapse? Dis Colon Rectum 2014;57:1446-1447.

10. Esen E, Aytac E, Ağcaoğlu O, Zenger S, Balik E, Baca B, Hamzaoğlu I, Karahasanoğlu T, Buğra D. Totally Robotic Versus Totally Laparoscopic Surgery for Rectal Cancer. Surg Laparosc Endosc Percutan Tech 2018;28:245-249

11. Atasoy D, Aghayeva A, Bayraktar O, Pirinc N, Aytac E, Baca B, Karahasanoglu T, Hamzaoglu I. Roboticventral mesh rectopexy technique for rectal intussusceptionwith rectocele-a video vignette. Colorectal Dis 2017;19:947

12. D'Hoore a, Penninckx F. Laparoscopic ventral recto (colpo) pexy for rectal prolapse: surgical technique and outcome for 109 patients. Surg Endosc 2006;20:1919-1192.

13. Mackenzie H, Dixon AR. Proficiency gain curve and predictors of outcome for laparoscopic ventral mesh rectopexy. Surgery 2014;156:158-167.

14. Perrenot C, Germain A, Scherrer ML, Ayav A, Brunaud L, Bresler L. Longterm outcomes of robot-assisted laparoscopic rectopexy for rectal prolapse. Dis Colon Rectum 2013;56:909-914.
15. Heemskerk J, de Hoog DE, van Gemert WG, Baeten CG, Greve JW, Bouvy ND. Robot-assisted versus conventional laparoscopic rectopexy for rectal prolapse: a comparative study on costs and time. Dis Colon Rectum 2007;50:1825-1830.

16. Wong MT, Meurette G, Rigaud J, Regenet N, Lehur PA. Robotic Versus Laparoscopic Rectopexy for Complex Rectocele: A Prospective Comparison of Short-Term Outcome. Dis Colon Rectum 2011;54:342-346.

17. Bachoo P, Brazzelli M, Grant A. Surgery for complete rectal prolapse in adults. Cochrane Database Syst Rev 2000;CD001758.

18. Mäkelä-Kaikkonen J, Rautio T, Klintrup K, Takala H, Vierimaa M, Ohtonen $\mathrm{P}$, Mäkelä J. Robotic assisted and laparoscopic ventral rectopexy in the treatment of rectal prolapse: a matched-pairs study of operative details and complications. Tech Coloproctol 2014;18:151-155.

19. Mantoo S, Podevin J, Regenet N, Rigaud J, Lehur PA, Meurette G. Is robotic-assisted ventral mesh rectopexy superior to laparoscopic ventral mesh rectopexy in the management of obstructed defecation? Colorectal Dis 2013; 15:e469-e475.

20. Mehmood RK, Parker J, Bhuvimanian L, Qasem E, Mohammed AA, Zeeshan M, Grugel K, Carter P, Ahmed S. Short-term outcome of laparoscopic versus robotic ventral mesh rectopexy for full-thickness rectal prolapse. Is robotic superior? Int J Colorectal Dis 2014;29:1113-1118.

21. Faucheron JL, Trilling B, Barbois S, Sage PY, Waroquet PA. Day case robotic ventral rectopexy compared with day case laparoscopic ventral rectopexy: a prospective study. Tech Coloproctol 2016;20:695-700.

22. Inaba CS, Sujatha-Bhaskar S, Koh CY, Jafari MD, Mills SD, Carmichael JC, Stamos MJ, Pigazzi A. Robotic ventral mesh rectopexy for rectal prolapse: a single-institution experience. Tech Coloproctol 2017;21:667-671.

23. Swain SK, Kollu SH, Patooru VK, Munikrishnan V.Robotic ventral rectopexy: Initial experience in an Indian tertiary health-care centre and review of literature. J Minim Access Surg 2018;14:33-36.

24. Brunner M, Roth H, Günther K, Grützmann R, Matzel KE. Ventral rectopexy with biological mesh: short-term functional results. Int J Colorectal Dis 2018;33:449-457

25. Franceschilli L, Varvaras D, Capuano I, Ciangola CI, Giorgi F, Boehm G, Gaspari AL, Sileri P. Laparoscopic ventral rectopexy using biologic mesh for the treatment of obstructed defaecation syndrome and/or faecal incontinence in patients with internal rectal prolapse: a critical appraisal of the first 100 cases. Tech Coloproctol 2015;19:209-219.

26. Ramage L, Georgiou P, Tekkis P, Tan E. Is robotic ventral mesh rectopexy better than laparoscopy in the treatment of rectal prolapse and obstructed defecation? A meta-analysis. Tech Coloproctol 2015;19:381-389.

27. Abet E, Lehur PA, Wong M, Rigaud J, Darnis E, Meurette G. Sexual function and laparoscopic ventral rectopexy for complex rectocoele. Colorectal Dis 2012;14:e721-726.

28. van Iersel JJ, de Witte CJ, Verheijen PM, Broeders IAMJ, Lenters E, Consten ECJ, Schraffordt Koops SE. Robot-Assisted Sacrocolporectopexy for Multicompartment Prolapse of the Pelvic Floor: A Prospective Cohort Study Evaluating Functional and Sexual Outcome. Dis Colon Rectum 2016:59:968-974

29. Rondelli F, Bugiantella W, Villa F, Sanguinetti A, Boni M, Mariani E, Avenia N. Robot-assisted or conventional laparoscoic rectopexy for rectal prolapse? Systematic review and meta-analysis. Int J Surg 2014;12 Suppl 2:S153-S159.

30. Smart NJ, Pathak S, Boorman P, Daniels IR. Synthetic or biological mesh use in laparoscopic ventral mesh rectopexy-a systematic review. Colorectal Dis 2013;15:650-654

31. Evans C, Stevenson AR, Sileri P, Mercer-Jones MA, Dixon AR, Cunningham C, Jones OM, Lindsey I. A Multicenter Collaboration to Assess the Safety of Laparoscopic Ventral Rectopexy. Dis Colon Rectum 2015;58:799-807.

32. de Hoog DE, Heemskerk J, Nieman FHM, van Gemert WG, Baeten CG, Bouvy ND. Recurrence and functional results after open versus conventional laparoscopic versus robot-assisted laparoscopic rectopexy for 
rectal prolapse: a case control study. Int J Colorectal Dis 2009;24:12011206.

33. Mäkelä-Kaikkonen J, Rautio T, Pääkkö E, Biancari F, Ohtonen P, Mäkelä J. Robot-assisted vs laparoscopic ventral rectopexy for external or internal rectal prolapse and enterocele: a randomized controlled trial. Colorectal Dis 2016;18:1010-1015.

34. Mantoo S, Rigaud J, Naulet S, Lehur PA, Meurette G.Standardized surgical technique and dedicated operating room environment can reduce the operative time during robotic-assisted surgery for pelvic floor disorders. J Robot Surg 2014;8:7-12.

35. Madiba TE, Baig MK, Wexner SD. Surgical management of rectal prolapse. Arch Surg 2005;140:63-73.

36. Cadeddu F, Sileri P, Grande M, De Luca E, Franceschilli L, Milito G. Focus on abdominal rectopexy for full-thickness rectal prolapse: meta-analysis of literature. Tech Coloproctol 2012;16:37-53.
37. Germain A, Perrenot C, Scherrer ML, Ayav C, Brunaud L, Ayav A, Bresler L. Long-term outcome of robotic-assisted laparoscopic rectopexy for fullthickness rectal prolapse in elderly patients. Colorectal Dis 2014;16:198202.

38. Wong MTC, Abet E, Rigaud J, Frampas E, Lehur PA, Meurette G.Minimally invasive ventral mesh rectopexy for complex rectocoele: impact on anorectal and sexual function. Colorectal Dis 2011;13:e320-326.

39. Mäkelä-Kaikkonen JK, Rautio TT, Koivurova S, Päkkö E, Ohtonen P, Biancari F, Mäkelä JT.Anatomical and functional changes to the pelvic floor after robotic versus laparoscopic ventral rectopexy: a randomised study. Int Urogynecol J 2016;27:1837-1845.

40. Consten ECJ, van Iersel JJ, Verheijen PM, Broeders IAMJ, Wolthuis AM, D'Hoore A. Long-term Outcome After Laparoscopic Ventral Mesh Rectopexy: An Observational Study of 919 Consecutive Patients. Ann Surg 2015;262:742-747; discussion 747-748. 